\title{
Guide to LIVING MAMMALS
}

\author{
J. E. WEBB \\ Professor of Zoology, Westfield College \\ University of London \\ J. A. WALLWORK \\ Reader in Zoology, Westfield College, \\ University of London \\ J. H. ELGOOD \\ Formerly Associate Professor of Zoology, \\ University of Ibadan, Nigeria
}

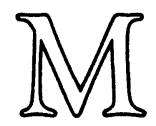


ISBN 978-1-349-04914-1 ISBN 978-1-349-04912-7 (eBook)

DOI 10.1007/978-1-349-04912-7

(C) J. E. Webb, J. A. Wallwork, J. H. Elgood 1977

All rights reserved. No part of this publication

may be reproduced or transmitted, in any form or by any

means, without permission

First published 1977 by

THE MACMILLAN PRESS LTD

London and Basingstoke

Associated companies in New York Dublin

Melbourne Johannesburg and Madras

ISBN 978-0-333-21696-5

This book is sold subject to the standard conditions of the Net Book Agreement.

The paperback edition of this book is sold subject to the condition that it shall not, by way of trade or otherwise, be lent resold, hired out, or otherwise circulated without prior consent in any form of binding or cover other than that in which it is published and without a similar condition including this condition being imposed on the subsequent purchaser. 


\section{Preface}

This Guide to the Living Mammals is the second in a series intended to cover the animal kingdom and to provide, through an annotated classification of the groups, a basic understanding of the animals they contain. Like the first volume, Guide to Invertebrate Animals, most of the material and its mode of presentation has been used for a number of years in the training of students so that the mammal guide has evolved slowly as a result of this experience.

Although the concept developed in these books is the same, that is the learning of structure and relationships of animals through classification, they differ in a number of ways. In the mammals we are considering variety within a single class many of the members of which are familiar to most people. Among the invertebrates this was not the case. Here we had a wide range of organisms mostly known only to those with a special interest in animals and representing a number of fundamentally different types of structural organisation.

The mammals demonstrate perhaps better than any other group the effects of change in land form and climate on the distribution of animals. A major feature of this guide, therefore, is the inclusion of maps showing the areas occupied by all the important groups where distribution becomes significant. Such maps are, of course, only an approximation indicating the probable range of the wild forms. They do not give the present day distribution of domesticated and other mammals such as the horse, camel, rabbit and deer that have been spread by Man far beyond the areas where they are indigenous. 
There are many books on the mammals, but three in particular supplement the brief treatment in this guide giving valuable additional information on classification, structure and distribution. The Principles of Classification and a Classification of Mammals by G.G. Simpson (Bull. Amer. Mus. nat. Hist. 85,1945$)$ is an excellent conspectus of the group. Recent Mammals of the World by S. Anderson and J. Knox Jones, Ronald Press, New York, 1967, is specially useful for the characters of the families and distribution, while the Traite de Zoologie by Grasse, volume 17 (in two parts), Masson, Paris, 1955, is an encyclopaedic treatment in French of the anatomy, behaviour and systematics of the mammalian orders.

We are again grateful to Mrs. Margaret Clarke for the preparation of the typescript for photolithography. We also thank Phil Brookes who made the drawings of the animals which are an essential part of the book.

\author{
JEW \\ JAW \\ JHE \\ London, July 1976
}




\section{Contents}

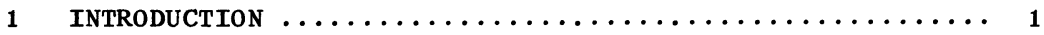

2 EGG-LAYING, MARSUPIAL AND PlACENTAL MAMMALS $\ldots \ldots \ldots \ldots \ldots 5$

Class Mammalia ....................... 6

Subclass Prototheria, Order Monotremata ........ 12

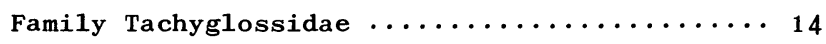

Family Ornithorhynchidae ............ 15

Subclass Metatheria, Order Marsupialia ........ 16

Superfamily Didelphoidea ............. 21

Superfamily Dasyuroidea .............. 22

Superfamily Perameloidea .............. 23

Superfamily Caenolestoidea .............. 24

Superfamily Phalangeroidea ............ 25

Subclass Eutheria .................. 26

3 INSECTIVORA, FLYING LEMURS AND BATS $\ldots \ldots \ldots \ldots \ldots \ldots \ldots$

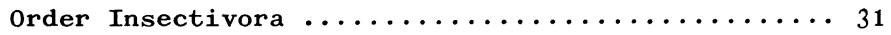

Family Tenrecidae $\ldots \ldots \ldots \ldots \ldots \ldots \ldots \ldots \ldots \ldots \ldots \ldots$

Family Solenodontidae .............. 34

Family Chrysochloridae ............. 35

Family Erinaceidae ................ 36

Family Soricidae ................ 37

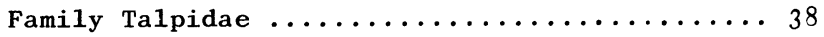

Family Macroscelididae .............. 39

Order Dermoptera ................... 40

Order Chiroptera .................... 41

Suborder Megachiroptera, Family Pteropidae ..... 42

Suborder Microchiroptera .............. 43 
Order Primates ............................ 49

Suborder Prosimii ..................... 50

Family Tupaiidae ..................... 51

Family Lemuridae .................... 52

Family Indridae ..................... 52

Family Daubentoniidae ................. 52

Family Lorisidae ..................... 54

Suborder Tarsii, Family Tarsiidae ........... 55

Suborder Simii ....................... 56

Family Cebidae ..................... 58

Family Callithricidae ................. 58

Family Cercopithecidae ................. 60

Family Pongidae ...................... 61

Family Hominidae ...................... 62

5 ANTEATERS AND ALLIES ............................ 63

Order Edentata, Suborder Xenarthra ............ 64

Family Myrmecophagidae .................. 66

Family Bradypodidae .................. 67

Family Dasypodidae .................... 68

Order Pholidota ....................... 69

6 LAGOMORPHS AND RODENTS ....................... 70

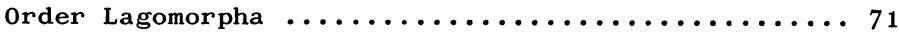

Order Rodentia .......................... 73

Suborder Sciuromorpha $\ldots \ldots \ldots \ldots \ldots \ldots \ldots \ldots \ldots$

Suborder Myomorpha $\ldots \ldots \ldots \ldots \ldots \ldots \ldots \ldots \ldots$

Suborder Hystricomorpha $\ldots \ldots \ldots \ldots \ldots \ldots \ldots$

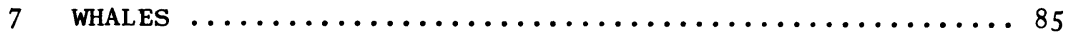

Order Cetacea ........................... 86

Suborder odontoceti ................... 88

Suborder Mysticeti ..................... 91

8 CATS, DOGS AND SEALS ......................... 94

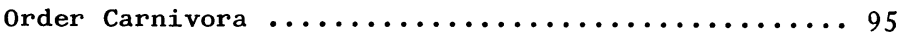

Family Procyonidae ...................... 97

Family Ursidae ......................... 98

Family Mustelidae ....................... 99

Family Canidae ....................... 100 
Page
Page

Family Viverridae ..................... 101

Family Hyaenidae ..................... 102

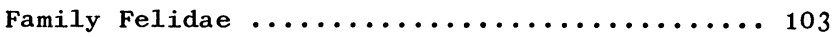

Order Pinnipedia ......................... 104

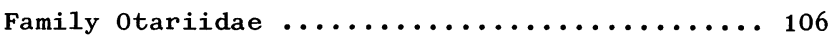

Family Odobenidae ...................... 107

Family Phocidae ......................... 108

9 THE PRIMITIVE UNGULATES .......................... 109

Order Tubulidentata ..................... 110

Order Proboscidea ........................ 111

Order Hyracoidea ......................... 113

Order Sirenia ........................ 115

PERISSODACTYLES ............................ 116

Order Perissodactyla .................... 117

Suborder Ceratomorpha ................... 119

Family Tapiridae ..................... 119

Family Rhinocerotidae ................. 119

Suborder Hippomorpha, Family Equidae ......... 121

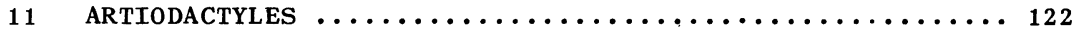

Order Artiodactyla .................... 123

Suborder Suiformes .................... 124

Family Suidae ...................... 126

Family Tayassuidae ................... 127

Family Hippopotamidae .................. 128

Suborder Tylopoda, Family Camelidae .......... 129

Suborder Tragulina, Family Tragulidae ........ 131

Suborder Pecora ........................ 132

Family Cervidae ........................ 133

Family Giraffidae .................... 134

Family Antilocapridae ................. 135

Family Bovidae ....................... 136

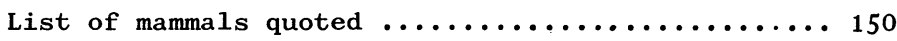

